\title{
PENGARUH MODEL PEMBELAJARAN KOOPERATIF TIPE STAD DAN TAPPS DITINJAU DARI GAYA BELAJAR SISWA KELAS V SDN DI KECAMATAN KALITIDU BOJONEGORO
}

\author{
Nur Rohman, S.Pd., M.Pd \\ Dosen Prodi Pendidikan Matematika IKIP PGRI Bojonegoro \\ Email: nurrohmanspd62@yahoo.co.id
}

\begin{abstract}
Abstrak. Penelitian ini merupakan jenis penelitian quasi - eksperimen dengan desain faktorial 3x3. Populasi penelitian adalah semua siswa di kelas V semester I Sekolah Dasar Negara 2013/2014 di Kabupaten Kecamatan Kalitidu Bojonegoro . Sampel penelitian diambil dengan menggunakan teknik stratified random sampling. Data penelitian diuji dengan menggunakan uji statistik uji normalitas dengan rumus dan homogenitas uji Lilliefors dengan rumus Bartlett dengan $\alpha=0,05$. Data sekolah ' nilai ujian akhir yang terkena menyeimbangkan uji dengan menggunakan analisis satu arah varians dengan sel yang tidak sama . Hipotesis penelitian diuji dengan menggunakan analisis dua arah varians dengan sel yang tidak sama. Teknik analisis data yang digunakan analisis dua arah tidak seimbang varian. Hasil penelitian adalah: ( 1 ) Tapps belajar dan pembelajaran Ekspositori memiliki prestasi matematika persamaan garis lurus lebih baik daripada STAD , berarti sementara pembelajaran Ekspositori memiliki prestasi matematika persamaan garis lurus yang sama seperti belajar Tapps , ( 2 ) Dalam setiap kelompok belajar gaya ( visual, auditori , kinestetik ), adalah sama prestasi matematika persamaan garis lurus , ( 3 ) Dalam setiap gaya belajar kelompok, belajar Tapps dan pembelajaran Ekspositori untuk mempengaruhi prestasi matematika persamaan garis lurus lebih baik dari STAD dan Tapps belajar untuk mempengaruhi prestasi matematika sama dengan pembelajaran Ekspositori .
\end{abstract}

Kata kunci: STAD, Tapps , Ekspositoris , Gaya Belajar

\section{PENDAHULUAN}

Rendahnya prestasi belajar matematika masih menjadi masalah yang serius bagi dunia pendidikan di Indonesia, baik tingkat SD, SMP, maupun SMA. Berdasarkan hasil survei internasional Trends In International

\section{Mathematics And Science Study (TIMSS)}

oleh Puspendik yaitu skor prestasi matematika siswa di Indonesia berada signifikan di bawah rata-rata internasional. Indonesia pada tahun 2003 berada di peringkat ke-35 dari 46 negara, dan tahun 2007 berada di peringkat ke-36 dari 49 negara (http://litbangkemdiknas.net/detail. php?id=214). Berdasarkan data dalam Education For All (EFA) Global Monitoring
Report 2011, Organisasi Pendidikan, Ilmu Pengetahuan, dan Kebudayaan Perserikatan Bangsa-Bangsa (UNESCO), menempatkan Indonesia di posisi ke-69 dari 127 negara di dunia. Indonesia masih tertinggal dari Brunei yang berada di peringkat ke-34 yang masuk kelompok pencapaian tinggi bersama Jepang yang mencapai posisi nomor satu di dunia. Sementara Malaysia berada di peringkat ke65 (http://herdy07.wordprress.com).

Pada mata pelajaran matematika, sepatasnya kita perlu prihatin. Matematika yang posisinya sebagai "ratu" sekaligus "pelayan" dari ilmu pengetahuan dan teknologi justru menjadi mata pelajaran yang dianggap paling sulit bahkan menjadi momok dalam setiap kegiatan belajar mengajar. Akhirnya apa yang diharapkan dari prestasi 
belajar matematika, ternyata masih jauh dari harapan.

Pemilihan model pembelajaran yang tepat akan membantu siswa untuk lebih aktif dalam belajar, sehingga proses dan hasil belajar siswa diharapkan dapat meningkat. Selanjutnya, belajar akan lebih bermakna apabila siswa secara aktif mengumpulkan informasi yang diperoleh dan menggabungkannya untuk memperoleh suatu konsep matematika yang pada akhirnya akan memberi hasil belajar matematika yang baik.

Beberapa model pembelajaran antara lain pembelajaran Ekspositori, STAD dan TAPPS. Pembelajaran ekspositori adalah pembelajaran yang digunakan dengan memberikan keterangan terlebih dahulu, definisi, prinsip dan konsep materi pelajaran serta memberikan contoh latihan pemecahan masalah dalam bentuk ceramah, demonstrasi, tanya jawab dan penugasan. Menurut Erman Suherman (2003: 203 ) yang biasa dinamakan mengajar matematika dengan metode ceramah (seperti dalam satuan pelajaran) menurut penjelasan di atas sebenarnya adalah model ekspositori. Pembelajaran kooperatif tipe STAD menurut Majokal, Dad \& Tariq (2010) menyatakan bahwa:

"Student Team Achievement Division (STAD) is a cooperative learning strategy in which small groups of learners with diferent levels of ability work together to accomplish a shared learning goal"

STAD adalah strategi pembelajaran kooperatif dimana kelompok-kelompok kecil peserta didik dengan berbagai tingkat kemampuan bekerja sama untuk mencapai tujuan belajar bersama. Pembelajaran kooperatif tipe Thinking Aloud Pairs Problem Solving (TAPPS) yang dikenalkan oleh Claparade. TAPPS merupakan salah satu model pembelajaran dengan menggunakan pendekatan pemecahan masalah, yang juga mampu melibatkan siswa secara aktif dalam pembelajaran. Ide dasar pembelajaran menggunakan TAPPS adalah bagaimana memotivasi siswa dalam kelompok agar mereka dapat saling membantu dan mendorong satu sama lain dalam menguasai materi yang disajikan. Dengan menggunakan TAPPS, diharapkan siswa dapat saling membantu dalam rangka menumbuhkan kemampuan pemecahan masalah matematika.

Selain model pembelajaran, faktor lain yang mempengaruhi keberhasilan suatu proses pembelajaran adalah siswa sendiri. Pada diri siswa mempunyai karakteristik yang dapat mempengaruhi kegiatan belajar siswa antara lain: latar belakang pengetahuan, taraf pengetahuan, motivasi belajar, gaya belajar, tingkat kematangan, kemampuan awal, lingkungan sosial ekonomi, kecerdasan, dan lain-lain. Terkait dengan gaya belajar, gaya belajar merupakan cara belajar siswa yang lebih disukai dalam melakukan kegiatan berpikir, memproses dan mengerti suatu informasi. Menurut Adi W. Gunawan yang dikutip oleh Ria Noviana Agus (2010: 3), hasil riset menunjukkan bahwa murid yang belajar dengan gaya belajar mereka yang dominan saat 
mengerjakan tes, akan mencapai nilai yang jauh lebih tinggi dibandingkan bila mereka belajar dengan cara yang tidak sejalan dengan gaya belajar mereka.Pembelajaran konvensional yang cenderung memberikan materi melalui ceramah akan memudahkan bagi siswa dengan gaya belajar auditori karena dengan mendengarkan siswa dapat dengan mudah memahami materi yang dipelajari, tetapi belum tentu bagi siswa dengan belajar visual maupun kinestetik, yang mungkin dapat menimbulkan kesulitan memahami materi yang sedang dipelajari karena materi tidak dapat dilihat dan tidak memerlukan keterlibatan siswa secara langsung. Pembelajaran berbasis masalah yang memberikan orientasi siswa sebagai permasalahan pada awal pembelajaran akan memudahkan siswa dengan gaya belajar auditori yang fasih berbicara, tetapi belum tentu memberikan kemudahan bagi siswa dengan gaya belajar visual maupun kinestetik yang cenderung tidak fasih berbicara.

Adapun tujuan penelitian ini adalah untuk mengetahui: 1) manakah yang memberi pengaruh lebih baik, pembelajaran Ekspositori, STAD atau TAPPS terhadap prestasi belajar materi operasi bilangan bulat? 2) manakah yang memberi pengaruh lebih baik dalam pembelajaran, siswa dengan gaya belajar visual, auditori, atau kinestetik terhadap prestasi belajar materi operasi bilangan bulat? 3) pada siswa dengan berbagai gaya belajar, manakah model pembelajaran yang memberi pengaruh lebih baik, model pembelajaran Ekspositori, STAD atau TAPPS terhadap prestasi belajar operasi bilangan bulat?

\section{METODE PENELITIAN}

Penelitian ini merupakan penelitian eksperimental semu (quasi-experimental research). Budiyono (2003:81) menyatakan bahwa tujuan penelitian eksperimen semu adalah untuk memperoleh informasi yang merupakan perkiraan bagi informasi yang dapat diperoleh dengan eksperimen yang sebenarnya dalam keadaan yang tidak memungkinkan untuk mengontrol dan atau memanipulasi semua variabel yang relevan.

Menurut Budiyono (2009:121), populasi adalah keseluruhan pengamatan yang ingin diteliti berhingga atau tak berhingga. Populasi penelitian ini adalah peserta didik kelas V SD Negeri sekecamatan Kalitidu Bojonegoro tahun palajaran 2013/2014, yang berjumlah 40 SD Negeri, dibagi berdasarkan peringkat nilai UAN, yaitu: (1) SD Negeri peringkat tinggi (14 SD), (2) SD Negeri peringkat sedang (14 SD), (3) SD Negeri peringkat bawah (12 SD). Dari masing-masing peringkat dipilih secara random 3 SD Negeri melalui teknik random sampling sebanyak 9 SD. 3 SD sebagai kelas ekperimen 1, 3 SD sebagai kelas eksperimen 2, dan 3 SD sebagai kelas kontrol.

Teknik pengumpulan data menggunakan 3 cara yaitu: 1) dokumentasi, berupa nilai rapor semester genap kelas IV tahun pelajaran 2012/2013 untuk mengetahui kemampuan awal, apakah populasi dalam keadaan normal, homogen dan akhirnya 
seimbang, 2) angket, berupa seperangkat pernyataan untuk mengetahui gaya belajar yang dimiliki siswa dan 3) tes, berupa seperangkat butir soal, untuk mengetahui prestasi belajar setelah siswa mengalami model pembelajaran. Sebelum instrumen angket digunakan, dilakukan uji validitas, uji konsistensi internal (Karl Person) dan uji reliabilitas (Alpha Cronbach), sedangkan instrumen tes prestasi terlebih dahulu dilakukan analisis validitas, daya pembeda, tingkat kesukaran dan uji relibilitas (KR-20).

Teknik analisis data dalam penelitian ini adalah: 1) uji keseimbangan, menggunakan anava satu jalan sel tak sama dengan uji prasyarat uji normalitas dengan metode Lilliefort dan uji homogenitas dengan uji Bartllet, 2) uji hipotesis, menggunakan anava dua jalan sel tak sama, (Budiyono,2009: 229). 3) uji komparasi ganda, dengan menggunakan metode Scheffe. Semua analisis penelitian ini menggunakan tingkat signifikansi $5 \%$ dan perhitungan menggunakan Microsoft Office Excel 2007.

\section{HASIL DAN PEMBAHASAN}

Untuk mengetahui kemampuan awal populasi, apakah dalam keadaan normal, homogen dan seimbang kemampuannya, maka dilakukan uji normalitas, uji homogenitas yang pada akhirnya uji keseimbangan. Hasil dari uji normalitas populasi siswa dengan pembelajaran TAPPS adalah $\mathrm{L}_{\text {obs }}=0.0923<\mathrm{L}_{\mathrm{tab}}=0.0955$, berarti $\mathrm{H}_{\mathrm{o}}$ diterima. Uji normalitas populasi siswa dengan pembelajaran STAD adalah $\mathrm{L}_{\text {obs }}=$
$0.0905<\mathrm{L}_{\mathrm{tab}}=0.0944$, berarti $\mathrm{H}_{\mathrm{o}}$ diterima. Uji normalitas populasi siswa dengan pembelajaran Ekspositori adalah $\mathrm{L}_{\text {obs }}=$ $0.0888<\mathrm{L}_{\mathrm{tab}}=0.0961$, berarti $\mathrm{H}_{\mathrm{o}}$ diterima. Dengan demikian ketiga populasi dalam keadaan normal. Antar ketiga populasi pembelajaran pada uji homogenitas diperoleh $\chi_{\text {obs }}^{2}=2.535<\chi_{\text {tab }}^{2}=5.991$ sehingga $\mathrm{H}_{0}$ diterima, berarti variansi ketiga populasi homogen. Hasil uji keseimbangan antara populasi pembelajaran TAPPS, STAD dan Ekspositori diperoleh $\mathrm{F}_{\mathrm{obs}}=1.695<\mathrm{F}_{\mathrm{tab}}=3.000$ sehingga Ho diterima, berarti ketiga populasi dalam keadaan seimbang.

Pengolahan data hasil penelitian agar dapat digunakan uji anava adalah uji normalitas populasi siswa dengan pembelajaran TAPPS adalah $\mathrm{L}_{\mathbf{o b s}}=0.0898<$ $\mathrm{L}_{\mathrm{tab}}=0.0955$, berarti $\mathrm{H}_{\mathrm{o}}$ diterima. Uji normalitas populasi siswa dengan pembelajaran STAD adalah

$\mathrm{L}_{\text {obs }}=0.0926<\mathrm{L}_{\text {tab }}=0.0944$, berarti $\mathrm{H}_{\mathrm{o}}$ diterima. Uji normalitas populasi siswa dengan pembelajaran Ekspositori adalah $\mathrm{L}_{\mathbf{o b s}}$ $=0.0835<\mathrm{L}_{\mathrm{tab}}=0.0961$, berarti $\mathrm{H}_{\mathrm{o}}$ diterima. Dengan demikian ketiga populasi dalam keadaan normal. Antar ketiga populasi pembelajaran dari uji homogenitas diperoleh $\chi_{\text {obs }}^{2}=4.872<\chi_{\text {tab }}^{2}=5.991$ sehingga $\mathrm{H}_{0}$ diterima, berarti variansi ketiga populasi homogen. Uji normalitas populasi siswa dengan gaya belajar visual adalah $\mathrm{L}_{\mathbf{o b s}}=$ $0.1103<\mathrm{L}_{\mathrm{tab}}=0.1229$ berarti $\mathrm{H}_{\mathrm{o}}$ diterima. Uji normalitas populasi siswa dengan gaya belajar auditori adalah $\mathrm{L}_{\text {obs }}=0.0709<\mathrm{L}_{\text {tab }}=$ 0.0721 berarti $\mathrm{H}_{\mathrm{o}}$ diterima. Uji normalitas 
populasi siswa dengan gaya belajar kinestetik adalah $\mathrm{L}_{\mathrm{obs}}=0.1142<\mathrm{L}_{\mathrm{tab}}=0.1184$, berarti $\mathrm{H}_{\mathrm{o}}$ diterima. Dengan demikian ketiga populasi dalam keadaan normal. Untuk ketiga populasi gaya belajar pada uji homogenitas diperoleh $\chi_{\text {obs }}^{2}=0.068<\chi_{\text {tab }}^{2}=$ 5.991 sehingga $\mathrm{H}_{0}$ diterima, berarti variansi ketiga populasi homogen. Adapun rerata tes hasil belajar berdasarkan model pembelajaran dan gaya belajar diperoleh seperti pada tabel berikut:

Tabel 1

Rerata Tes Prestasi Belajar Siswa Pada Model Pembelajaran dan gaya belajar

\begin{tabular}{|c|c|c|c|c|}
\hline \multirow{2}{*}{ Pembelajaran (A) } & \multicolumn{3}{|c|}{ Gaya Belajar (B) } & \multirow{2}{*}{$\begin{array}{r}\text { Rerata } \\
\text { Marginal }\end{array}$} \\
\hline & Visual & Auditori & Kinestetik & \\
\hline TAPPS & 54,2857 & 53,5455 & 50,8571 & 53,0698 \\
\hline STAD & 40,7059 & 42,4615 & 44,5263 & 42,5682 \\
\hline Ekspositori & 46,5714 & 51,2727 & 47,0000 & 49,6941 \\
\hline Rerata Marginal & 47,7692 & 48,9007 & 47,6071 & \\
\hline
\end{tabular}

Setelah prasyarat analisis variansi terpenuhi, sama yang hasilnya seperti rangkuman dilakukan uji hipotesis anava dua jalan sel tak analisis variansi dua jalan berikut:

Tabel 2

Rangkuman Analisis Variansi Dua Jalan

\begin{tabular}{|l|r|r|r|r|r|c|}
\hline \multicolumn{1}{|c|}{ Sumber } & \multicolumn{1}{c|}{ JK } & \multicolumn{1}{c|}{ Dk } & \multicolumn{1}{c|}{ RK } & \multicolumn{1}{c|}{$\mathbf{F}_{\text {obs }}$} & \multicolumn{1}{c|}{$\mathbf{F}_{\text {tab }}$} & Kep. Uji \\
\hline \hline $\begin{array}{l}\text { Pembelajaran } \\
\text { (A) }\end{array}$ & 3609.1518 & 2 & 1804.6403 & 11.5235 & 3.000 & $\mathrm{H}_{0 \mathrm{~A}}$ ditolak \\
\hline $\begin{array}{l}\text { Gaya Belajar } \\
\text { (B) }\end{array}$ & 143.0454 & 2 & 71.5227 & 0.4567 & 3.000 & $\mathrm{H}_{0 \mathrm{~B}}$ diterima \\
\hline Interaksi (AB) & 470.8872 & 4 & 117.7218 & 0.7517 & 2.370 & $\mathrm{H}_{0 \mathrm{AB}}$ diterima \\
\hline Galat & 39151.2932 & 250 & 156.6052 & & & \\
\hline Total & 43374.5064 & 258 & & & & \\
\hline
\end{tabular}

Berdasarkan Tabel 2 di atas, diketahui bahwa pada efek utama (A), ada pengaruh model pembelajaran kooperatif tipe TAPPS, STAD dan pembelajaran Ekspositori terhadap prestasi belajar siswa pada materi operasi bilangan bulat, artinya tidak semua model pembelajaran memberi prestasi belajar yang sama, pada efek utama (B), tidak ada pengaruh gaya belajar visual, auditori dan kinestetik terhadap prestasi belajar pada materi operasi bilangan bulat, artinya ketiga gaya belajar memberi prestasi belajar yang sama dan pada efek interaksi (AB), tidak ada interaksi antara pembelajaran yang digunakan dan gaya belajar terhadap prestasi belajar matematika.

Karena $\mathrm{H}_{0 \mathrm{~A}}$ ditolak maka dilakukan uji komparasi rerata antar baris. Dari uji 
komparasi rerata antar baris didapat hasil seperti tabel rangkuman uji komparasi rerata antar baris berikut :

Tabel 3

Rangkuman Uji Komparasi Rerata Antar Baris

\begin{tabular}{|c|c|c|c|}
\hline Ho & $\mathrm{F}_{\text {obs }}$ & $\begin{array}{c}\text { Nilai } \\
\text { Kritis } \\
(2 . \mathrm{F} \\
0.05 ; 2250)\end{array}$ & $\begin{array}{c}\text { Keputusan } \\
\text { Uji }\end{array}$ \\
\hline$\mu_{1}=\mu_{2 .}$ & 30.6292 & 6.0000 & Ho ditolak \\
\hline$\mu_{1}=\mu_{3 .}$ & 3.1105 & 6.0000 & $\begin{array}{c}\text { Ho } \\
\text { diterima }\end{array}$ \\
\hline$\mu_{2}=\mu_{3 .}$ & 14.0195 & 6.0000 & Ho ditolak \\
\hline
\end{tabular}

Kesimpulan berdasarkan Tabel 3 di atas adalah: pada $\mu_{1}=\mu_{2}$. keputusan uji Ho ditolak, dengan memperhatikan rerata marginal $\bar{x}_{1 .}=53,0698$ dan $\bar{x}_{2 .}=42,5682$ menunjukkan bahwa pembelajaran tipe TAPPS memberi pengaruh yang lebih baik dibanding dengan pembelajaran STAD terhadap prestasi belajar siswa . Pada $\mu_{1}=$ $\mu_{3}$. keputusan uji Ho diterima, maka pembelajaran tipe TAPPS dan Ekspositori memberi pengaruh yang sama terhadap prestasi belajar siswa. Pada $\mu_{2}=\mu_{3}$. keputusan uji Ho ditolak, dengan memperhatikan rerata marginal $\bar{x}_{2 .}=42,5682$ dan rerata marginal $\bar{x}_{3 .}=49,6941$ menunjukkan bahwa pembelajaran Ekspositori memberi pengaruh yang lebih baik dibanding pembelajarn STAD terhadap prestasi belajar siswa.

Untuk uji komparasi antar kolom yaitu antara gaya belajar, dari analisis variansi dua jalan diputuskan bahwa $\mathrm{H}_{0 \mathrm{~B}}$ diterima, sehingga dapat disimpulkan bahwa antara gaya belajar visual, auditori dan kinestetik memberikan pengaruh yang sama terhadap prestasi belajar siswa.

Untuk uji komparasi antar sel pada kolom yang sama yaitu antara model pembelajaran dan gaya belajar, dari analisis variansi dua arah diputuskan bahwa $\mathrm{H}_{0 \mathrm{AB}}$ diterima. Dari hasil uji komparasi antar baris dan uji komparasi antar kolom, maka dapat disimpulkan: 1) berdasarkan gaya belajar, bahwa siswa dengan gaya belajar visual, auditori dan kinestetik menunjukkan bahwa prestasi belajar matematika siswa pada pembelajaran TAPPS dan Ekspositori memberi pengaruh yang lebih baik daripada siswa pada pembelajaran STAD, sedangkan pada pembelajaran TAPPS memberi pengaruh yang sama dengan siswa pada pembelajaran Ekspositori. 2) berdasarkan model pembelajaran, bahwa siswa pada pembelajaran kooperatif tipe TAPPS, pembelajaran STAD dan pembelajaran Ekspositori menunjukkan bahwa baik gaya belajar viasual, auditori maupun kinestetik memberi pengaruh yang sama terhadap prestasi belajar matematika.

Pembahasan hasil penelitian berdasarkan hipótesis di atas adalah:

Dari hipótesis pertama, diperoleh kesimpulan bahwa pembelajaran tipe TAPPS memberi pengaruh yang lebih baik dibanding dengan pembelajaran STAD terhadap prestasi belajar siswa, pembelajaran tipe TAPPS dan Ekspositori memberi pengaruh yang sama terhadap prestasi belajar siswa, pembelajaran Ekspositori memberi pengaruh yang lebih 
baik dibanding pembelajaran STAD terhadap prestasi belajar siswa.

Dari beberapa hasil penelitian yang relevan, pembelajaran STAD lebih efektif daripada pembelajaran langsung (Sulani, 2010: 75-76), Selama proses model pembelajaran TAPPS diterapkan, usaha para siswa untuk belajar terwujud dengan baik dalam komunikasi dan argumentasi logika di antara sesama siswa sekelas di dalam kelompok tersebut. Selain itu pada pembelajaran ini siswa dapat mencari informasi dari beberapa sumber, adanya pembagian tugas dalam kelompok dan berani menyampaikan ide-ide dalam diskusi serta adanya rasa tanggung jawab menyelesaiakan tugas kelompok. Hal ini menunjukkan bahwa di penelitian ini TAPPS telah mendukung kemampuan kelompok pada siswa secara keseluruhan. Pada pembelajaran Ekspositori siswa mendapatkan kemudahan dalam memahani materi karena model pembelajaran ini kata beberapa siswa sebelumnya digunakan dalam kelas sementara pada model STAD rasa tanggungjawab setiap anggota kelompok pada materi yang berbeda menjadi beban tersendiri. Tingkat kedewasaan siswa ternyata juga belum mampu mendukung penerapan model pembelajaran STAD.

Dari hipotesis kedua, diperoleh kesimpulan bahwa antara gaya belajar visual, auditori dan kinestetik berdasarkan prestasi belajar siswa memberikan pengaruh yang sama terhadap prestasi belajar matematika. Hal ini tidak sama dengan hipotesis kedua yang peneliti ambil. Dalam penelitian ini, untuk ketiga model pembelajaran yang diterapkan peneliti mendorong siswa untuk belajar dari berbagai gaya belajar yang dimiliki pada diri siswa sendiri. Dari ketiga gaya belajar yang dimiliki siswa pada penelitian ini, khususnya pada pokok bahasan operasi bilangan bulat, ketiga gaya belajar tersebut dimanfaatkan oleh siswa dalam proses pembelajaran. Dengan demikian, selama proses pembelajaran siswa belajar melalui kombinasi dari ketiga gaya belajar tersebut. Siswa belajar melalui gaya belajar visual, auditori dan kinestetik. Hal ini sesuai dengan eksistensi teori gaya belajar, bahwa siswa belajar melalui berbagai macam cara. Akibatnya, dalam penelitian ini diperoleh bahwa antara gaya belajar visual, auditori dan kinestetik memberikan prestasi belajar matematika yang sama.

Dari hipotesis ketiga, berdasarkan analisis variansi dua arah dengan sel tak sama disimpulkan $\mathrm{F}_{\mathrm{obs}}=0.7517<\mathrm{F}_{0,05 ; 2 ; 259}=2.370$ $\left(\mathrm{H}_{0 \mathrm{AB}}\right.$ diterima $)$ berarti tidak ada interaksi antara pembelajaran yang digunakan dan gaya belajar terhadap prestasi belajar matematika. Namun jika dilihat efek utamanya dapat disimpulkan bahwa pada siswa dengan gaya belajar visual, pembelajaran TAPPS memberi pengaruh yang lebih baik daripada pembelajaran STAD terhadap presetasi belajar matematika, pembelajaran TAPPS memberi pengaruh yang sama dengan Ekspositori, pembelajaran Ekspositori memberi pengaruh yang lebih baik daripada pembelajaran STAD terhadap prestasi belajar siswa, Pada siswa dengan 
gaya belajar auditori, pembelajaran TAPPS memberi pengaruh yang lebih baik daripada pembelajaran STAD terhadap presetasi belajar matematika, pembelajaran TAPPS memberi pengaruh yang sama dengan Ekspositori, pembelajaran Ekspositori memberi pengaruh yang lebih baik daripada pembelajaran STAD terhadap prestasi belajar siswa. Pada siswa dengan gaya belajar kinestetik, pembelajaran TAPPS memberi pengaruh yang lebih baik daripada pembelajaran STAD terhadap presetasi belajar matematika, pembelajaran TAPPS memberi pengaruh yang sama dengan Ekspositori, pembelajaran Ekspositori memberi pengaruh yang lebih baik daripada pembelajaran STAD terhadap prestasi belajar siswa. Jadi secara umum disimpulkan bahwa dari ketiga gaya belajar baik gaya belajar visual, auditori dan kinestetik siswa dengan pembelajaran TAPPS dan Ekspositori memberi prestasi belajar lebih baik daripada pembelajaran STAD. Sedangkan pembelajaran TAPPS memberi prestasi belajar yang sama baiknya dengan pembelajaran Ekspositori.

\section{SIMPULAN DAN SARAN}

\section{Kesimpulan}

Kesimpulan penelitian ini adalah: 1) Pembelajaran TAPPS dan Pembelajaran Ekspositori memberi pengaruh yang lebih baik daripada Pembelajaran STAD terhadap prestasi belajar siswa, sedangkan Pembelajaran Ekspositori memberi pengaruh yang sama baiknya dengan Pembelajaran
TAPPS terhadap prestasi belajar siswa, 2) antara gaya belajar visual, auditori dan kinestetik memberi pengaruh yang sama terhadap prestasi belajar siswa, 3) dari ketiga gaya belajar visual, auditori maupun kinestetik, pembelajaran TAPPS dan Ekspositori memberi pengaruh yang lebih baik daripada pembelajaran STAD terhadap prestasi belajar siswa, sedangkan pembelajaran TAPPS memberi pengaruh yang sama dengan pembelajaran Ekspositori terhadap prestasi belajar siswa.

\section{Saran}

Berdasarkan hasil penelitian ini peneliti sarankan bahwa: 1) untuk materi operasi bilangan bulat sebaiknya dalam pembelajaran menerapkan model pembelajaran kooperatif tipe TAPPS atau jika ingin model pembelajaran non kooperatif sebaiknya menggunakan pembelajaran Ekspositori, 2) untuk materi operasi bilangat bulat dominansi gaya belajar yang dimiliki siswa tidak perlu dipermasalahkan karena gaya belajar yang dimiliki siswa tidak memberi pengaruh yang berbeda pada model pembelajaran TAPPS, STAD maupun Ekspositori.

\section{DAFTAR PUSTAKA.}

Budiyono, 2003. Metodologi Penelitian Pendidikan. Surakarta: Sebelas Maret University Press.

Budiyono. 2009. Statistik Untuk Penelitian Edisi ke 2. Surakarta: SebelasMaret University Press.

Erman Suherman, dkk. 2003. Strategi Pembelajaran Matematika Konteporer Bandung: JICA FPMIPA Universitas Pendidikan Indonesia 
Herdy. 2001. Education For All Global Monitoring Report. (http://herdy07. wordprress.com). Diakses pada 15 Juli 2013 09:39:17.

Majokal, M. I., Dad, M. H., \& Mahmood, T. 2010, Student Team Achievement Division (STAD)as an Active Learning Strategy: Empirical Evidence From Mathematics Classroom. Journal of Education and Sociology, ISSN: 2078032X, Desember, 2010. Page 1.

Puspendik. 2011. Survei Internasional TIMSS. http://litbangkemdiknas.net/ detai. php?id=214. Diunduh pada 10 Agustus 2013, 10:45:16.

Ria Noviana Agus. 2010. Efektivitas Pembelajaran Matematika Melalui
Pendekatan Realistics Mathematics Education (RME) Dengan Pemecahan Masalah dan Realistic Mathematics Education (RME) Ditinjau Dari Gaya Belajar.

Slavin, R.E. 2008. Cooperative Learning, Teori, Riset dan Praktik. Bandung :Nusa Media

Sulani. 2010. Eksperimentasi Model Pembelajaran STAD Pada Materi Pokok Sistem Persamaan Linier Ditinjau dari Motivasi Belajar Siswa Kelas X SMA Negeri Se-Kabupaten Tulungagung Tahun Ajaran 2009/2010. Tesis. Program Pascasarjana Universitas Sebelas Maret 